The Geneva Papers on Risk and Insurance, 19 (No. 70, January 1994), 37 - 45

\title{
Should a Regulatory Body Control Insurance Policies Ex Ante or Is Ex Post Control More Effective?
}

\author{
by Per-Olof Bjuggren*, Dan Magnusson** and Carl Martin Roos***
}

\section{Introduction}

This paper deals with the much debated issue of control of insurance provisions. The topic is part of the broader area standard contracts law and unfair provision in standard contracts. By standard contracts or adhesion contracts we mean contracts that are concluded without the adhering party's power to influence the provisions in question.

Standard contracts have a valuable function in the market economy. Without the use of standard contracts, transaction costs would be much higher. Insurance policies are typically standard contracts. Consumers must accept consumer insurance policies as they are or refuse to enter into an insurance contract. The same is true for most industrial insurance, although larger enterprises may sometimes negotiate "tailor-made" policies.

From a legal viewpoint, standard contracts are problematic. They do not fit into the framework of traditional contract law, which is based on individually negotiated contracts. General rules on entering into a contract and construction of contract clauses do not easily apply to standard contracts. Furthermore, the fact that the producer or manufacturer formulates the contract's provisions without cooperating with the other party brings up the possibility of abusive practices.

This calls for methods to restrict the use of unfair or unconscionable contract clauses. The current paper focuses on possible ways to prevent unfair clauses in insurance policies.

* Assistant professor in Economics at Linköping University, Sweden. Sweden.

** Doctor in Sociology of Law at the National Council for Crime Prevention, Stockholm,

*** Professor in Commercial Law at Jönköping International Business School, Sweden.

Presented at the EALE/Geneva Association Conference on the Law and Economics of Insurance and Services in Geneva, on April 5-6, 1993.

The authors wish to thank Göran Hägg, Michael Faure, Paul Fenn and participants at the EALE/Geneva Association Conference for valuable comments and Charles Stuart for helpful suggestions and language improvements. 
Theoretically, many methods are available. One possibility is simply to allow competition to prevent unfair clauses. Competition in insurance markets and repeated trade can function as control mechanisms both ex ante and ex post. A related method is to allow agreed documents, which means that representatives of insurers and insured negotiate on the policy conditions; this method may restrict competition to some degree. It is sometimes used in marine insurance.

Supervision of contract provisions can also be performed by a state authority. This alternative is especially interesting in insurance because insurance plans are commonly controlled by supervisory agencies for other reasons. The supervision of insurance can be performed cx ante or ex post. In addition to supervision by a state authority, disputes over contractual provisions can be subject to arbitration procedures of different kinds. Voluntarily arbitration and advice can be provided by organizations established by insurers, customers, and municipal and state authorities. In this picture, litigation and a court decision play the role of a last resort.

The role of contracts in the transacting proccss is considered in section 2. In section 3 and 4, different theoretical aspects of ex ante and ex post control systems are presented. The Swedish system of control is described in section 5. Concluding remarks are in section 6 .

\section{Transacting and contracting}

In our analysis we restrict attention to consumer insurance. Insurance companies, wich are generally large and have historically established reputations, transact with individual persons, who are much less informed about the peculiarities of the trade. Different kinds of transaction costs are present. First search and information costs are borne, followed by negotiation and contract costs, and finally there are police and enforcement costs. To a large extent the magnitude of these costs reflects transaction problems that arise when information asymmetry leads to adverse selection and moral hazard. In terms of the transacting process, adverse selection (or hidden information) can be considered as a precontractual phenomenon and moral hazard (or hidden action) as a post-contractual phenomenon. If the insurance contract is carefully drawn, both of these problems can sometimes be mitigated. Use of different kinds of guarentees from the insured in a contract can serve as an alternative to search and information activities as devices for avoiding adverse selection. Compensation can in the contract be made contingent on the actions of the insured in ways that reduce moral hazard and thereby also reduce the police and enforcement costs.

The frequency of transactions differs between the insurance companies and the insured. In contrast to the insured the insurance company participates in a large number of transactions that are subject to problems of risk and hidden action. By offering standardized contracts, contract costs and thereby also transaction costs can be reduced. At the same time insurance markets may have a two-sided informational asymmetry. In adverse selection and moral hazard it is the insured who has an information advantage and as a consequence can benefit from opportunistic behavior toward the insurer. In pre-formulated contracts the asymmetry may be the opposite. Learning-by-transacting gives the insurance company an information advantagc vis-à-vis the insured. The insurer can behave opportunistically and make the insured accept "unfair" contract terms. According to Lando (1978, p. 166) "many people are often unable to understand the meaning of the terms of the contract" and "many - perhaps most - people do not give careful attention to the terms of their contracts". 
In a postcontractual phase, conflicts about the "unfairness" of contract terms can emerge, where the insured claims that he or she did not realize the consequences of signing the pre-formulated contract. How should these conflicts be resolved ex post? Or should these conflicts be avoided by ex ante supervision of standardized contracts?

The question can be thought as involving a choice between complete and incomplete contracting. A system of ex ante control by the state could, if it functions perfectly, be viewed from the perspectives of classical contract law (see e.g. Macneil, 1978). The formulation of the contract is carefully prescribed by a legal authority or supervised with respect to legality. Conflicts are to be resolved by the court. In an ex post system, the direct role of the government is minimal in participating in the construction of complete contracts; contract formulation is to a large extent decentralized and private, and the fact that standardized insurance contracts can be incomplete is recognized. The focus is instead on different kinds of governance institutions (including courts) in dealing with the problems of unfairness that can arise ex post in incomplete contracts.

In modern institutional economics, contracting is studied from perspectives similar to those outlined above. In the mechanism-design literature, the optimal contract between a principal and an agent under conditions of asymmetric information is studied. The derived optimal contract is complete and subsequently all conflicts are most efficiently solved by a court. The mechanism-design approach to contracting is thus in accordance with an ex ante system.

The transaction cost analysis of Williamson (1985 and 1989) views contracting from another angle. Bounded rationality and a "propensity to behave opportunistically" are assumed to be two characteristics of the human being. As a consequence, contracts are more or less bound to be incomplete. Because of this incompleteness, it is necessary to create institutions that support the contract ex post. In the words of Williamson (1989, p. 139):

"...the ex post side of a contract takes on special economic importance. The study of structures that facilitate gapfilling, dispute settlement, adaptation, and the like thus become part of the problem of economic organization. Whereas such institutions play a central role in the transaction cost economics scheme of things, they are ignored (indeed, suppressed) by the fiction of comprehensive ex ante contracting."

In contrast to the mechanism-design approach, the transaction cost analysis can be used to explain both ex ante regulation and ex post governance of contracts. The two systems of control are complementary, insofar as ex ante regulation can reduce contract gaps that are unnecessary for adaptive purposes. If ex ante regulation in this way enhances the quality of contracts, the costs of ex post governance can be reduced. An efficient institutional structure for ex ante control and ex post supervising or governing on contracts is one that maximizes transaction net benefits (i.e. maximizes the difference between benefits provided and costs insurred ex ante and ex post in transactions, see Kreps 1990, ch 20). The court is more or less a last resort to resolve conflicts due to incompleteness.

\section{Ex ante control}

Standard contracts could be scrutinized and approved by a supervision agency before they are used in actual transactions. This way of conducting business has been adopted in the Standard Contracts legislation in Israel, where a board of representatives for different interests approves standard contracts ex ante and makes them legally valid for continued 
use. Germany and Austria are two European countries with ex ante control systems (see Kimball and Pfennigstorf, 1968). In most states in the US fire insurance contracts have to be standardized in a prescribed manner (Williams and Heins, 1985, pp. 288-289). The ex ante solution has also been recommended by Lando (1966-1978).

If an ex ante solution is chosen, the consumer can rely on the tested document and may be less sensitive than otherwise to the "fairness" of different pre-formulated clauses. The members of the supervision agency have expert knowledge of anticipated consequences of contract terms and therefore may have an informational advantage relative to ordinary consumers.

However, there are several drawbacks with such an organizational solution. The first is the duplication of cost in having all pre-formulated contracts scrutinized by both the formulating seller and the supervising agency. (With ex post control, selective intervention can be relied upon). A drawback that may be more severe is the negative effect on the innovation process and the waste of local information that is likely to take place in a regime of ex ante control. The rationality of the supervisor is bounded. Contracts must be scrutinized without complete knowledge of how the contracts will work in practice and which problems and conflicts that may occur.

It is commonly said that the best and most accurate information of how to come to grips with adverse selection and moral hazard as well as the best and most relevant actuarial knowledge are likely to be found at the company level (cf. Hayek, 1945). The central supervising agency is from time to time likely to be confronted with new unfamiliar contract terms. How will these unfamiliar contract terms be dealt with by an agency that may be held responsible for mistakes in the approval of contract terms?

Two types of errors can be made by an agency in dealing with unfamiliar contract terms. First, contract terms that are "unfair" can by mistake be approved (let us call this a Type 1 error). Second, contract terms that are "fair" can by mistake be disapproved (Type 11 error). The agency is more likely to be held responsible for Type 1 errors than for Type 11 errors, as it is easier to discover and prove mistakes of the first type. This suggests that the agency would have a greater incentive to minimize Type 1 errors than Type 11 errors.

The probable outcome of an ex ante control system is thus that the agency would be too restrictive in approval of unfamiliar contract terms. That is, the innovation process would be delayed. Relatively many resources would have to be spent by companies to persuade the agency of the "fairness" of proposed contract terms. At the same time, some information might not be transmitted to the agency if this led to too detailed disclosure of a contractual innovation. In such cases, the firm faces a trade off between revealing trade secrets and increasing the probability of approval of unfamiliar contract terms.

As presented in section 2, the creation of a well-functioning ex ante system can be seen as a mechanism-design problem. Similar to the mechanism-design model, the objective is to choose complete comprehensive contracts where courts are relied upon for enforcement of contracts. In contrast to transaction costs analysis, bounded rationality and opportunism do not impede the construction of complete contracts in the mechanism-design model.

However, if bounded rationality of supervisors and opportunism are present, a central supervising agency is unlikely to know the characteristics of complete contracts. Furthermore, a central supervising agency does not have any informational advantage about contract terms, fair or unfair. Instead, it is the individual insurance company that is likely to have the best knowledge of appropriate contract terms. 
An advantage of an ex ante system might be that the supervising agency has no incentives to behave opportunistically toward insured individuals. An underlying assumption is in such cases that supervisors are not "captured" by insurance companies. ${ }^{1}$ Even if supervisors are rewarded according to their ability to screen unfair terms there are as pointed out above other shortcomings of an ex ante system. Finally unfamiliar terms are not likely to be accepted, so competition in the insurance market seen from a dynamic and process-oriented viewpoint would be hampered.

At best, a contract that meets the need of a hypothetical average insured would be approved. It is difficult and costly, however, to take the special circumstances of different insureds into account. As a result, adaptability to special and changing circumstances would be low in an ex ante system.

\section{Ex post control}

More common is that supervision is performed ex post. Ex post control can be based on intervention from the authorities and from the courts, and on recommendations from special complaints boards. An advantage with this last method is that it uses local information and promotes diversity and innovation. A probable outcome is that more risks are insurable. A reservation is that ex post control might not protect the consumer against unfair contract terms to the same extent as an ex ante control. To compare the two systems, the question of how well ex post supervision protects the consumer against "unfair" contract terms must be addressed.

A control mechanism of special relevance in an ex post system is competition among the different insurance companies. One way for an individual company to obtain more sales is to offer more attractive terms to the consumers. A rational and well-informed consumer might then have a real choice between different standard contracts. Rivalry between sellers would then drive out contracts with "unfair" terms. In this sense the problem is not that contracts are standardized. The problem is instead a lack of competition (see Posner 1973). Disregarding fraud, the only contract term that is likely to be unfair in an insurance market in which cooperation between sellers and entry barriers lead to monopolistic prising is the premium.

There are also other ways of exercising control over the fairness of contract terms. Intervention through authorities, the courts and special claims boards are examples. The legal instruments that can be used for control purposes in these cases are manifold. Unfair contract provisions can be overruled by mandatory legislation. In the insurance field, this type of protective legislation appears in insurance contracts legislation, especially when it comes to safe-guarding the interests of the consumers. Furthermore, there may exist principles of interpretation in general contract law that help maintain fair and reasonable contract clauses, and there may also exist special legal provisions that help eliminate unreasonable and unfair clauses.

Insurance contract law that is non-mandatory and thus only supplements a contract may also help support conscionable solutions. In such cases, the consumer must be more active and the outcome is more uncertain if the consumer complains about contract terms

\footnotetext{
1 For a presentation of "capture" and insurance regulation, see e.g. Noll (1989) and Joskow and Rose (1989).
} 
that ex post are experienced as "unfair". The incentive of the consumer to take such more active legal steps depends on the relation between his/her expected costs and benefits of such a procedure (see Cooter and Rubinfeld 1989). If the costs are reduced through legal insurance, state subsidies, or in other ways, the consumer would be more inclined to take legal steps.

Removal of unfair contract terms might, however, also be in the interest of insurers. Unfairness of a contract term does not have to be due to opportunistic behavior. The insurance company can have made a mistake. As insurance companies repeatedly trade in the market, the reputation of being an honest seller is a valuable asset. It is therefore in the intcrest of the company not to be involved in legal disputes of unfair contract terms in preformulated contracts. For these reasons, advisory boards have been organized by insurance companies, overcompensation is often paid, and settlements are made even when it is likely that the contracts would not be considered unfair at trial (cf. Roos 1981).

Explanations of the efficiency of an ex post system can also be put more directly in the terms of the transaction cost model referred to in section 2. Bounded rationality makes most contracts incomplete. A number of ex post control mechanisms that safeguard against opportunistic behavior may thus be needed. Competition and repeated trade serve as such safeguards. However, competition and repeated trade does not fully characterize the workings of an ex post system. Governance institutions that are intentionally created to support contracts and trade must also be considered. Such governance institutions have been developed to give credibility that printed terms and gaps in standard contracts are not used opportunistically.

Contract supporting institutions can be created at different organizational levels of a society. In the next section we will describe how ex post institutions to support standard contracts have been structured in Sweden. It will be shown that there are supervision agencies at the central governmental level as well as at the municipal level. There are also voluntary bodies organized by the insurance companies. Finally, the courts serve as an ultimate control mechanism that curbs incentives for insurance companies to use unfair contract terms, at least when the costs for consumers to take legal steps are low.

\section{The Swedish system of control of insurance conditions}

The Financial Supervision Agency (Finansinspektionen) (and before 1991 the Insurance Supervision Agency [Försäkringsinspektionen]) has for many years been empowered to intervene against unfair insurance conditions. ${ }^{2}$ However, the possibility has seldom been used. Premium conditions have had greater priority than have problems with insurance conditions.

There has been a debate in Sweden if this administrative ex post control should be performed by the Financial Supervision Agency or by the General Consumer Agency (Konsumentverket) which is responsible for the control of unfair contracts in general. The legislature decided in 1976 that supervision should remain with the Insurance Supervision Agency (the predecessor of the Financial Supervision Agency in insurance matters). A motivation was that the supervision of premiums and the supervision of insurance conditions are interrelated, so it is difficult to separate control of premiums from control of insurance policies.

2 The Bank Supervision Agency (Bankinspektionen) and the Insurance Supervision Agency (Försäkringsinspektionen) merged in 1991 into the Financial Supervision Agency (Finansinspektionen). 
The most important control of insurance conditions is performed by consumers. The consumer may complain to the insurer if he/she thinks that an unfair condition has been applied. Several insurers have special Customer Ombudsmen who take care of complaints. Another alternative open to unhappy consumers is to turn to The National Board for Consumer Complaint (Allmänna Reklamationsnämnden, ARN), which is a governmental authority. The primary function of the Board is to try disputes between consumers and producers and to give recommendations as to how these disputes are to be settled. Cases can only be tried at the request of the consumer, provided that they concern products mainly intended for the private use of the consumer.

The National Board for Consumer Complaints is organized in eleven departments. One department handles insurance matters. The insurance department deals with claims settlements and interpretations of contract terms for personal and property insurance. The central board of the insurance department is composed by legal experts and representatives for consumers and insurers. During the financial year 1991/92, 829 insurance cases were tried (Annual Report 1991). Some consumer complaints are not tried. Most important among those not tried are cases involving negligence leading to traffic damages. Most cases involving home and house insurance and many cases concerning all-risks insurance are similarly not tried. More than half of the 829 cases were simple ones and were dealt with by a special secretariat. 400 of the cases were considered more complicated and were therefore tried by the central board. Of these, the claims of the consumers were totally or partly accepted in 94 cases (i.e. $23 \%$ ). Unfortunately, statistics concerning cases handled by the secretariat are not available.

The reason for the low share of accepted claims seems to be that insurance companies have well-established routines for settling damage claims. The fact that a considerable number of consumers nevertheless complain about the settlements is probably due to difficulties in understanding settlement conditions and also to the fact that consumers are not aware of the limitations that sometimes exist when claims for damages are settled.

In Sweden, it is common that consumer services are provided at the municipal level. These services are financed by the municipality. There is no law that forces the municipalities to provide these services. In spite of this, as of January 1, 1992, 254 out of the total of 286 municipalities offered free services on consumer matters. Of the services rendered at the municipal level, consumer complaints are most common. In 1991, these local services handled 3164 insurance cases, i.e. more than the National Board for Consumer Complaints (Magnusson 1992a). Out of the 400 cases that the Board handled in 1991/92, about 100 had been dealt with earlier by local agencies.

There are also a number of voluntary bodies within the insurance industry that deal with insurance complaints. These bodies are administered by the insurance companies or organizations related to insurance companies. Ten such organizations are officially listed by the National Board for Consumer Complaints. The ten voluntary organizations handled 7404 cases in 1991 that were submitted by private policy holders (Magnusson 1992 b).

Neither the national complaints board nor the voluntary bodies can make decisions that bind the parties legally. They can only recommend to the parties how to solve the conflict. Usually, the parties accept the view of the complaints board. The total number of consumer complaints handled by all the different ex post supervising agencies (courts 
excluded) is thus 11297 cases ( 829 cases by the National Board for Consumer Complaints, 3164 cases by the local municipal authorities and 7404 cases by voluntary bodies within the insurance industry).

The last resort is to go to court and have the conflict resolved by judgement. Litigation costs of the insured are then mostly covered by legal expense insurance or by the state. Normally, conflicts never reach this stage. A reason is that insurers try to avoid the negative publicity of court cases.

There are several legal instruments for dealing with the fairness of insurance conditions. In the first place, some types of clauses are prevented by mandatory rules. In other cases the issue of fairness can depend on the construction of the relevant clause. Then, principles for constructing and understanding clauses in standard contracts must be applied. Ultimately, there is the general contractual provision on the fairness of contract clauses, the Swedish Contracts Act art. 36. This general rule for mitigating contract clauses has been used in some cases by the courts in insurance conflicts (see Roos 1990).

\section{Concluding remarks}

In a comparative institutional analysis of the two systems of control of insurance policies, the ex ante versus the ex post system, the choice of explanatory model is critical. If bounded rationality and opportunism are human factors of great importance, the transaction cost model may be the most appropriate one. The rationale for the regulatory body considered here is then to solve the problem of unfair provisions in standard contracts. The only reason that an unfair contract term would cause a problem is opportunism. Institutional responses to opportunism must thus be at the center of the analysis.

A consequence of bounded rationality is that contracts are to some extent incomplete. If contract incompleteness is a feature that is of great importance in insurance transactions, the ex post system with a number of contract-supporting governance institutions is more efficient than an ex ante system. The Swedish system of ex post control can serve as an example. The elaborate institutional structure of the Swedish system and the ability of the many voluntary bodies to solve disputes give empirical support to the notion that an ex post system is in most cases more efficient than a system focusing on ex ante regulation of contracts. 


\section{REFERENCES}

Allmänna reklamationsnämnden (ARN), Annual Report 1991/92.

BERNITZ, U., (1987), Standardavtalsrätt, Stockholm, Marknadsrättsförlarget AB.

COOTER, R. D. and RUBINFELD, D. L., (1989), "Economic Analysis of Legal Disputes and Their Resolution", Journal of Economic Literature, 26 : $1067-1097$.

HAYEK, F., (1945), "The Use of Knowledge in Society", American Economic Review, 35 : 519-530.

JOSKOW, P. L. and ROSE, N.L., (1989), "The Effects of Economic Regulation", in R. Schmalensee and R. Willig, eds., Handbook of Industrial Organization, Amsterdam, North Holland.

KIMBALL, S.L. and PFENNIGSTORF, W., (1968), Versicherungsbedingungen unter Staatsaufsicht, Karlsruhe.

KREPS, D.M., (1990), A Course in Microeconomic Theory, Cambridge, Harvester Wheatsheaf.

LANDO, O., (1966), "Standardkontakter, et forslag og et perspectiv", Tidskrift for retsvidenskap.

LANDO, O., (1978), "The Scope of Application of Statutes on Unfair Contract Clauses", in G. Skogh, ed., Law and Economics - Report from a Symposium in Sweden 1977, Lund, Juridiska Föreningen i Lund.

MACNEIL, I. R., (1978), "Contracts: Adjustments of long-term economic relations under classical, neoclassical, and relational contract law", Northwestern University Law Review, 72 : 864-906.

MAGNUSSON, D., (1992 a), Kommunal reklamationshantering, Stockholm, Konsumentverket.

MAGNUSSON, D., (1992b), De frivilliga reklamationshämndernas verksamhet, Stockholm, Konsumentverket.

NOLL, R. G., (1989), "Economic Perspectives on the Politics of Regulation", in R. Schmalensee and R. Willig, eds., Handbook of Industrial Organization, Amsterdam, North Holland.

POSNER, R. A., (1972), Economic Analysis of Law, Boston, Little, Brown \& Co.

ROOS, C. M., (1981), “On Insurer Generosity”, Scandinavian Studies in Law.

ROOS, C. M., (1990), “Avtalslagen $36 \S$ och försäkring”, Nordisk Försäkringstidskrift.

WILLIAMS, C. A. and HEINS, R. M., (1985), Risk Management and Insurance, New York, McGrawHill.

WILliAMSON, O.E., (1985), The Economic Institutions of Capitalism, New York, The Free Press.

WILLIAMSON, O. E., (1989), "Transaction Cost Economics", in R. Schmalensee and R. Willig, eds., Handbook of Industrial Organization, Amsterdam, North-Holland. 